\title{
Modelling nitrous oxide emissions from cropland at the regional scale
}

\author{
Benoît GABRIELLE ${ }^{1}$ \\ Patricia LAVILLE ${ }^{1}$ \\ Odile DUVAL ${ }^{2}$ \\ Bernard NICOULLAUD ${ }^{2}$ \\ Jean-Claude GERMON² \\ Catherine HENAULT ${ }^{3}$ \\ ${ }^{1}$ INRA, AgroParisTech UMR1091 \\ Environnement et Grandes Cultures, \\ F-78850 Thiverval-Grignon, France. \\ Fax: (+33) 130815563 \\ <Benoit.Gabrielle@grignon.inra.fr> \\ 2 INRA, UR0272, Science du Sol, \\ BP 20619, \\ F-45166 Olivet, France \\ 3 INRA, Université de Bourgogne, \\ UMR1229 Microbiologie et Géochimie des Sols, \\ F-21065 Dijon, France
}

\section{Introduction}

Emissions from arable soils are a key item in the global nitrous oxide $\left(\mathrm{N}_{2} \mathrm{O}\right)$ budget, making up about half of the terrestrial biogenic emissions [1]. Since agricultural activities are gradually coming into focus in the greenhouse gas (GHG) budget calculations, precise estimates of current $\mathrm{N}_{2} \mathrm{O}$ emissions from arable land are being sought, along with possible means of abatement. However, compared to other $\mathrm{GHG}$ such as $\mathrm{CO}_{2}, \mathrm{~N}_{2} \mathrm{O}$ fluxes are of small magnitude and highly variable in space and time [2], being tightly linked to the local climatic sequence and soil properties. In national GHG inventories, the default recommended method is that defined by IPCC [3], currently being overhauled. It relates direct $\mathrm{N}_{2} \mathrm{O}$ emissions to the amount of fertilizer $\mathrm{N}$ applied based on a fixed emissions factor, thereafter noted $\mathrm{EF}_{\mathrm{d}}$. Although this method is relatively easy to implement, by combination with nationwide economic statistics, it ignores the effect of the above-mentioned characteristics. Also, it cannot be used directly to define crop management strategies that would mitigate $\mathrm{N}_{2} \mathrm{O}$ emissions, since it does not account for the effect of fertilizer $\mathrm{N}$ application (let alone other management practices) on crop growth and yield. In the last ten years, the prediction of $\mathrm{N}_{2} \mathrm{O}$ emissions within process-based agroecosystem models has emerged as a promising route to deal with these issues, primarily at the local scale to single out the effect of crop management practices [4]. Application on larger

\begin{abstract}
Arable soils are a large source of nitrous oxide $\left(\mathrm{N}_{2} \mathrm{O}\right)$ emissions, making up half of the biogenic emissions worldwide. Estimating their source strength requires methods capable of capturing the spatial and temporal variability of $\mathrm{N}_{2} \mathrm{O}$ emissions, along with the effects of crop management. Here, we applied a process-based model, CERES, with geo-referenced input data on soils, weather, and land use to map $\mathrm{N}_{2} \mathrm{O}$ emissions from wheat-cropped soils in three agriculturally intensive regions in France. Emissions were mostly controlled by soil type and local climate conditions, and only to a minor extent by the doses of fertilizer nitrogen applied. As a result, the direct emission factors calculated at the regional level were much smaller (ranging from 0.0007 to $0.0033 \mathrm{~kg} \mathrm{~N}_{2} \mathrm{O}-\mathrm{N} \mathrm{kg}_{-1} \mathrm{~N}$ ) than the value of 0.0125 $\mathrm{kg} \mathrm{N}_{2} \mathrm{O}-\mathrm{N} \mathrm{kg}_{-1} \mathrm{~N}$ currently recommended in the IPCC Tier 1 methodology. Regional emissions were far more sensitive to the soil microbiological parameter s governing denitrification and its fraction evolved as $\mathrm{N}_{2} \mathrm{O}$, soil bulk density, and soil initial inorganic $\mathrm{N}$ content. Mitigation measures should therefore target a reduction in the amount of soil inorganic $N$ upon sowing of winter crops, and a decrease of the soil $\mathrm{N}_{2} \mathrm{O}$ production potential itself. From a general perspective, taking into account the spatial variability of soils and climate thereby appears necessary to improve the accuracy of national inventories, and to tailor mitigation strategies to regional characteristics. The methodology and results presented here may easily be transferred to winter oilseed rape, whose has growing cycle and fertilser requirements are similar.
\end{abstract}

Key words: nitrous oxide, arable crops, modelling, regional scale

spatial scales has also been demonstrated at the regional, country and sub-continental levels [5-7]. However, it is complicated by the lack of adequate input data and the fact that models may not be robust to such upscaling. In terms of spatial resolution, the above examples involved 16 to $400 \mathrm{~km}^{2}$-wide elementary counties or grid squares, implying that models were run on 'average' soils resulting from the combination of the possibly wide range of soil types occurring in the elementary spatial unit considered. Short-range $(<1 \mathrm{~km})$ variability across agricultural fields was therefore likely to be smoothed out in these spatial extrapolations, which precludes a back-tracking of those zones with high emission potentials on which particular measures might be taken to reduce the efflux of $\mathrm{N}_{2} \mathrm{O}$. Also, it makes it impossible to compare the elementary cell-averaged flux with local, ground measurements, the level at which these plot-scale models were generally tested [7].

Upscaling to small areas with a much finer grain has also been reported [8]. The latter authors simulated $\mathrm{N}_{2} \mathrm{O}$ emissions in a 12-ha landscape by means of $50 \mathrm{~m} \times 50 \mathrm{~m}$ grid squares, and showed micro-relief to be responsible for emission 'hot-spots' accounting for most of the spatial variability in $\mathrm{N}_{2} \mathrm{O}$ efflux. They concluded that aggregation of $\mathrm{N}_{2} \mathrm{O}$ emissions at higher scales should be based on 'typical landscapes in which surface topography and soil type is accurately represented'. There is therefore a need for process-based inventories at an intermediate resolution between the field (1-100 ha) and county $\left(10-1000 \mathrm{~km}^{2}\right)$ levels, which would explicitly account for heterogeneities between individual soil types.

Here, we report results obtained on such a grain for $\mathrm{N}_{2} \mathrm{O}$ emissions from wheat-cropped soils, at the sub-regional level. Note that the methodology and results presented here may easily be transferred to winter oilseed rape, whose has growing cycle and fertilser requirements are similar. We used a crop model derived from CERES [9], which incorporates a module for $\mathrm{N}_{2} \mathrm{O}$ emissions [10]. The model was run on elementary units (vectorized contours) resulting from the combination of several information layers in three agricultural sub-regions in Central France. The model parameterization procedure was checked against ground measurements of $\mathrm{N}_{2} \mathrm{O}$ emissions in three test sites [11], and its spatial estimates compared to those obtained with the IPCC [3] method.

\section{Material and methods}

\section{The CERES-EGC model}

CERES-EGC was adapted from the CERES suite of soil-crop models [9], with a focus on the simulation of environmental outputs such as nitrate leaching and gaseous emissions of $\mathrm{N}_{2} \mathrm{O}$, ammonia and nitrogen oxides [10]. CERESEGC comprises sub-models for the major processes governing the cycles of water, carbon and nitrogen in soil-crop systems. A physical module simulates the transfer of heat, water 
and nitrate down the soil profile, as well as soil evaporation, plant water uptake and transpiration in relation to climatic demand. A microbiological module simulates the turnover of organic matter in the plow layer, involving both mineralization and immobilization of inorganic N. Lastly, crop net photosynthesis is a linear function of intercepted radiation according to the Monteith approach, with interception depending on leaf area index based on Beer's law of diffusion in turbid media. Crop N uptake is computed through a supply/demand scheme, with soil supply depending on soil nitrate and ammonium concentrations and root length density.

CERES-EGC includes NOE [12], a semiempirical sub-model simulating the production and reduction of $\mathrm{N}_{2} \mathrm{O}$ in agricultural soils through both the denitrification and nitrification pathways. The denitrification component of NOE is based on NEMIS [13], a model that expresses total denitrification of soil $\mathrm{NO}_{3}$ as the product of a potential rate with three unitless factors related to soil water content, nitrate content, and temperature. The fraction of denitrified nitrate that evolves as $\mathrm{N}_{2} \mathrm{O}$ is considered as constant for a given soil type, according to the experimental evidence provided by Hénault et al. [14]. In a similar fashion, nitrification is modeled as a Michaëlis-Menten reaction, with $\mathrm{NH}_{4}$ as substrate. The corresponding rate is multiplied by unitless modifiers related to soil water content and temperature. As for denitrification, a soil-specific proportion of total nitrification evolves as $\mathrm{N}_{2} \mathrm{O}$, following the results of Garrido et al. [15]. The two pathways are connected in that nitrification-derived $\mathrm{N}_{2} \mathrm{O}$ may be reduced to $\mathrm{N}_{2}$ by denitrification, should the two processes be simultaneously active. Unlike other $\mathrm{N}_{2} \mathrm{O}$ emission modules such as NGAS [16] or DNDC [6], NOE does not use the microbial respiration of organic $\mathrm{C}$ as a driver for denitrification.

CERES-EGC runs on a daily time step, and computes the various transformation rates of $\mathrm{N}$ with the following sequence: nitrification, denitrification, mineralization/immobilization, and crop uptake. This sequence reflects the priority order for possibly competing processes, such as denitrification and crop uptake of nitrate.

\section{Spatial simulations}

\section{Information layers}

The study area comprised three administrative 'agricultural sub-regions' of the Beauce region, lying approximately $200 \mathrm{~km}$ southwest of Paris, France: Beauce Chartraine (74,000 ha), Beauce Dunoise $(61,200 \mathrm{ha})$, and Faux-Perche
(48,200 ha). The sub-regions were delineated by French authorities as relatively homogeneous zones from the point of view of physical characteristics (climate, pedogenesis and geological substrate), and agricultural production systems. The majority of soils in Beauce Chartraine are thick clay loams (Haplic Luvisols [17]), either permeable upon limestone parent material, or less material developed on a flinty clay substrate. The mean annual rainfall is $600 \mathrm{~mm}$, and mean air temperature is $10.6^{\circ} \mathrm{C}$. Beauce Dunoise comprises mostly thin loamy clay soils (Haplic Calcisols), developed on calcareous layers. Mean annual rainfall is $636 \mathrm{~mm}$, and mean air temperature is $10.8^{\circ} \mathrm{C}$. Lastly, the soils in Faux-Perche are loamy Gleyic Luvisols, developed on a flint clay substrate. Mean annual rainfall is $783 \mathrm{~mm}$, and mean air temperature is $10.3^{\circ} \mathrm{C}$. Farming systems are based on cereal crops in the first two regions, and include some livestock production in FauxPerche.

Elementary simulation units were defined by overlaying spatial information on soil types, climate, land use and crop management available at various geographical or administrative levels. Only a fraction of the sub-regions was simulated, since we had chosen to focus on winter wheat. Wheat is the major arable crop in the area, being grown on $30 \%$ to $40 \%$ of total arable land. Each sub-region comprised 4 counties, at which level information on land use was available through agricultural census data and farmers declarations for European subsidies. Typical crop management practices for winter wheat were set based on a survey in the three sub-regions. Soils were parameterized based on a 1:250 000 scale soil map, organized into geographical units (SMU) containing a mixture of soil typological units (STU), following the model of the European Union soil map [18]. The soil data base attached with the map comprised geographical information (the shape of the SMUs) and quantitative data for each SMU: the occurrence of particular STUs within the SMU, and various descriptors characterizing the STUs. The SMUs covered between 3 and 19,000 ha, with an average size of 775 ha. Daily weather data was taken for each simulation unit from the closest station available, less than $20 \mathrm{~km}$ away from the centroid of the unit.

\section{Soil parameterization}

Various methods were combined to estimate the soil parameters of CERES-EGC. Some were readily-available as thematic fields in the soil data base: depth to parent material (down to $2 \mathrm{~m}$ ), which was used to set the simulation depth; maximum rooting depth (with an upper limit of $1.5 \mathrm{~m}$ ); the thickness of the various soil horizons along with their particle- size distribution and bulk density. Soil water contents at wilting point and field-capacity were estimated with pedo-transfer functions developed on a collection of c. 600 samples, mostly taken from the Paris basin, with contrasting textures [19]. The saturation water content, also required by CERES-ECC as input, was estimated with the pedo-transfer function originally proposed by CERES [9]. Topsoil organic matter content was also included based on a nationwide survey [20], and updated in the course of this study. Surface $\mathrm{pH}$ and $\mathrm{CaCO}_{3}$ contents were added to the data base using local references and expertise, and the same went with saturated hydraulic conductivity. The latter was estimated using only three classes centered on the following values: $0.02,0.08$, and $0.3 \mathrm{md}^{-1}$, respectively.

The $\mathrm{N}_{2} \mathrm{O}$ module of CERES-EGC involves a set of 3 microbiological parameters governing the processes of $\mathrm{N}_{2} \mathrm{O}$ production and reduction in soils, as detailed in [12]. They were measured in the laboratory in the experimental test site set up in each sub-region [11]. Unfortunately, the limited size of the data base currently available for these parameters precludes the definition of pedo-transfer functions for their spatial extension [12]. We thus simply applied the values obtained in the test site to the whole subregion, considering these sites representative of this area. The influence of this hypothesis on the final results was tested in the uncertainty analysis.

\section{Model running}

CERES-EGC was run in each of the elementary simulation units for a reference period running from mid-September, 1998, to midSeptember, 1999. Initial moisture content was set at $90 \%$ of the field-capacity content throughout the soil profile, based on simulations of the preceding cropping season. Initial nitrate and ammonium concentrations in the soil were set at 5 and $1 \mathrm{mg} \mathrm{N} \mathrm{kg}^{-1}$ soil, respectively, throughout the profile. It corresponds to a total residual $\mathrm{N}$ content of $80 \mathrm{~kg} \mathrm{~N} \mathrm{ha}^{-1}$ in the top $1 \mathrm{~m}$ of soil, which is the average of $\mathrm{N}$ stocks measured in the region at that time of year (B. Nicoullaud, unpublished data, 2003). Annual $\mathrm{N}$ deposition was neglected, being less than $4 \mathrm{~kg} \mathrm{~N} \mathrm{ha}^{-1}$ in the area [21]. Since the focus was on wheat-cropped soils, the area of the simulation units were corrected for the fraction of land cropped to wheat in these units. Aggregation of elementary fluxes within each sub-region yielded the total $\mathrm{N}_{2} \mathrm{O}$ efflux estimated from winter wheat crops over this sub-region.

Wheat management data was set according to the recommendations made by local advisory services. The mean doses of fertilizer $\mathrm{N}$ were $195 \mathrm{~kg} \mathrm{~N} \mathrm{ha}^{-1}$ in Beauce Dunoise and 
$215 \mathrm{~kg} \mathrm{~N} \mathrm{ha}^{-1}$ in Faux-Perche and Beauce Chartraine, split into three applications in spring. Only mineral fertilizers were considered (in the form of ammonium nitrate and urea), since organic forms are applied on only $2 \%$ of the cropland area in the region studied here, and make up less than $2 \%$ of the total amounts of fertilizer $\mathrm{N}$ applied.

\section{Model testing and uncertainty analysis}

One test site was set up in each sub-region to check the simulations of $\mathrm{N}_{2} \mathrm{O}$ emissions obtained with the regional parameterization procedure detailed in the above section. The sites were selected as representative of the sub-region, and involved a Haplic Luvisol in Beauce Chartraine (site name: La Saussaye; $\left.48^{\circ} 24^{\prime} \mathrm{N}, 1^{\circ} 34^{\prime} \mathrm{E}\right)$, a Haplic Calcisol in Beauce Dunoise (at Villamblain; $47^{\circ} 98^{\prime} \mathrm{N}, 1^{\circ} 34^{\prime} \mathrm{E}$ ), and a Gleyic Luvisol in Faux-Perche (at Arrou; $48^{\circ} 08^{\prime} \mathrm{N}, 1^{\circ} 06^{\prime} \mathrm{E}$ ) - FAO classification [22].

$\mathrm{N}_{2} \mathrm{O}$ emissions were monitored by the static chamber method using circular chambers ( $0.5 \mathrm{~m}$ in diameter and $0.15 \mathrm{~m}$ in height), with 8 replicates [10]. Other outputs were also monitored to test the simulation of intermediate variables: soil water and mineral $\mathrm{N}$ content, and crop growth [10]. The results of the tests are reported in a previous paper [11], which also includes an uncertainty analysis of the regional $\mathrm{N}_{2} \mathrm{O}$ fluxes originating from uncertain input parameters (soil and managementrelated), and to model prediction error.

\section{Results}

\section{Regional simulations}

Table 1 summarizes the simulation outputs for the three sub-regions, while figure 1 provides a geographical mapping of the emissions. In terms of spatial distribution, there were no marked differences between the sub-regions, which all presented a wide range of emission rates. Beauce Chartraine exhibited a longitudinal gradient with lower $\mathrm{N}_{2} \mathrm{O}$ fluxes to the East and higher fluxes to the West, whereas in FauxPerche the emission levels were vertically stratified from North to South. Conversely, Beauce Dunoise was rather homogeneous and centered in the mid-range values of $\mathrm{N}_{2} \mathrm{O}$ fluxes. When expressed per unit area, the mean $\mathrm{N}_{2} \mathrm{O}$ fluxes varied markedly across the regions, from $0.63 \mathrm{~kg} \mathrm{~N}_{2} \mathrm{O}-\mathrm{N} \mathrm{ha}^{-1} \mathrm{yr}^{-1}$ in Beauce Dunoise to $2.23 \mathrm{~kg} \mathrm{~N}_{2} \mathrm{O}-\mathrm{N} \mathrm{ha}^{-1} \mathrm{yr}^{-1}$ in Faux-Perche. This range was much lower than the $3.85-5.45 \mathrm{~kg}$ $\mathrm{N}_{2} \mathrm{O}-\mathrm{N} \mathrm{ha}^{-1} \mathrm{yr}^{-1}$ simulated in the test sites with the regional parameterization.

Within the sub-regions, the western half of Beauce Chartraine appeared particularly sensitive in the regional balance of $\mathrm{N}_{2} \mathrm{O}$ emissions. Other zones prone to $\mathrm{N}_{2} \mathrm{O}$ emissions could also be delineated, such as the northernmost and

Table 1. Emissions of $\mathrm{N}_{2} \mathrm{O}$ simulated within each sub-region (total and average per hectare), with a standard or zero dose of fertilizer N. Regional estimates obtained with the IPCC methodology are also reported (corresponding to the emissions due to fertilizer application).

\begin{tabular}{|lccccc|}
\hline Sub-region & $\begin{array}{c}\text { Total area } \\
\text { simulated }\end{array}$ & $\begin{array}{c}\text { Fertilizer } \\
\text { N dose }\end{array}$ & $\begin{array}{c}\text { Mean annual } \\
\mathbf{N}_{\mathbf{2}} \mathbf{O} \text { flux }\end{array}$ & $\begin{array}{c}\text { Regional } \\
\text { flux }\end{array}$ & $\begin{array}{c}\text { Regional Emission } \\
\text { Factor }\end{array}$ \\
\hline Beauce Chartraine & ha & $\mathrm{kg} \mathrm{N} \mathrm{ha}^{-1}$ & $\mathrm{~kg} \mathrm{~N}_{2} \mathrm{O}-\mathrm{N} \mathrm{ha}^{-1}$ & $\mathrm{~kg} \mathrm{~N}_{2} \mathrm{O}-\mathrm{N}$ & $\mathrm{kg} \mathrm{N}_{2} \mathrm{O}-\mathrm{N} \mathrm{kg}^{-1} \mathrm{~N}$ \\
& & 215 & 1.37 & 42,887 & 0.0016 \\
IPCC & 31,927 & 0 & 1.02 & 31,868 & \\
Beauce Dunoise & 23,474 & 215 & 3.42 & 117,731 & 0.0125 \\
& & 195 & 0.65 & 15,384 & 0.0007 \\
IPCC & 23,474 & 195 & 0.52 & 12,165 & \\
Faux-Perche & 16,578 & 215 & 3.13 & 80,692 & 0.0125 \\
& & 0 & 2.23 & 37,010 & 0.0033 \\
IPCC & 16,578 & 215 & 1.51 & 25,062 & \\
\hline
\end{tabular}

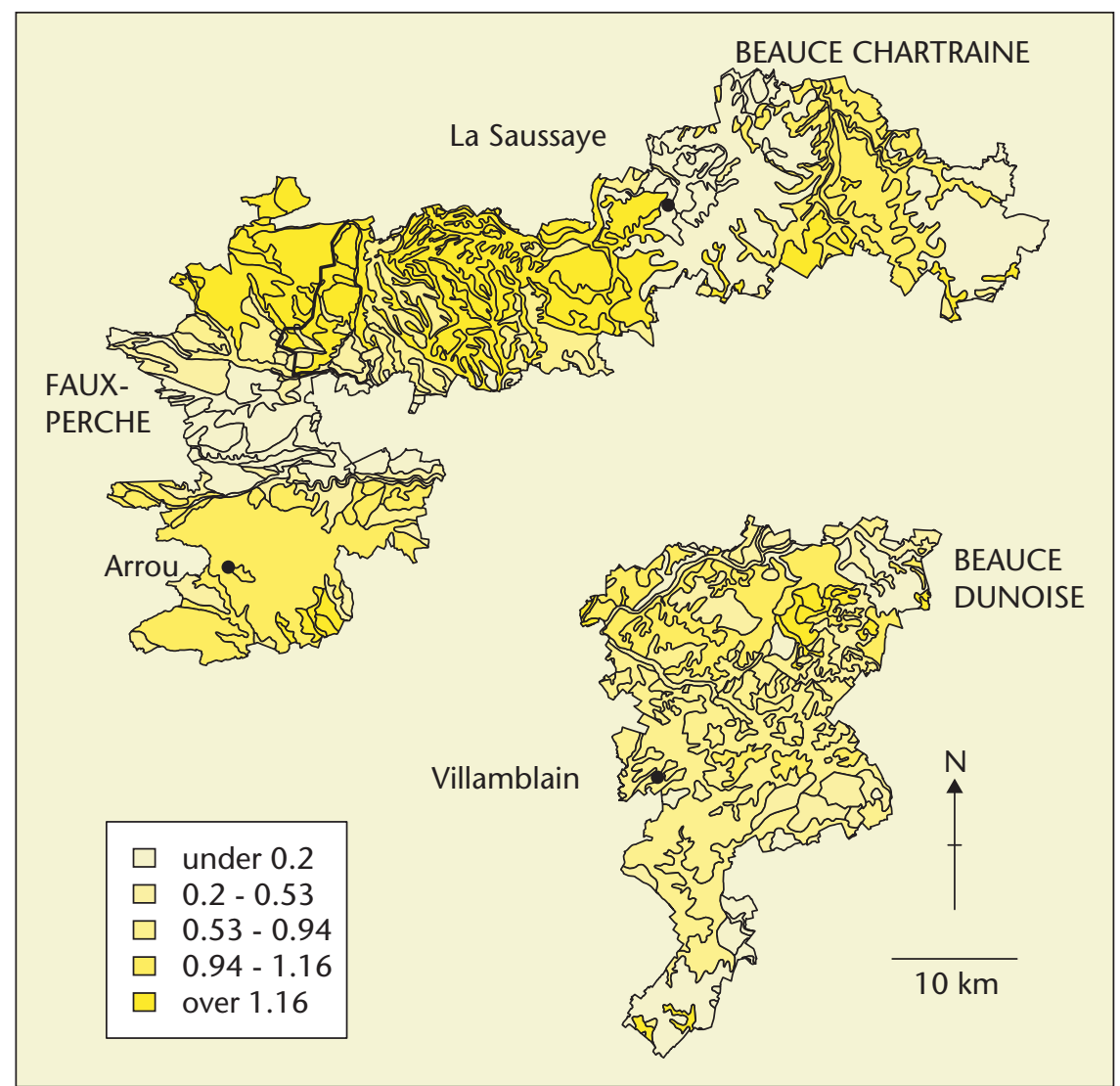

Figure 1. Simulation of $\mathrm{N}_{2} \mathrm{O}$ emissions from wheat-cropped land in three agricultural sub-regions of the Beauce region. The fluxes are expressed in $\mathrm{kg} \mathrm{N}_{2} \mathrm{O}-\mathrm{N} \mathrm{h}^{-1}$.

southernmost tips of Faux-Perche. Spatial structures in the other parts of the map were mostly determined by the spatial resolution of the soil map units (SMU), some of which were rather large with sizes ranging up to 19,000 ha. In addition, SMUs were made up of two to five different soil type units (STUs), with possibly contrasting potentials for $\mathrm{N}_{2} \mathrm{O}$ emission. On the other hand, emissions were much less vari- able within a given STU when it occurred across several map units and thereby climatic conditions. Figure 2 shows the distribution of fluxes across the various STUs to be strongly skewed, with an extended tail in the higher range of emissions (> $5 \mathrm{~kg} \mathrm{~N} \mathrm{ha}^{-1} \mathrm{yr}^{-1}$ ). However, the weight of this upper-tail was very limited, comprising only 11 STUs out of a total of 230 , and making up $0.7 \%$ of the total area simulated. 


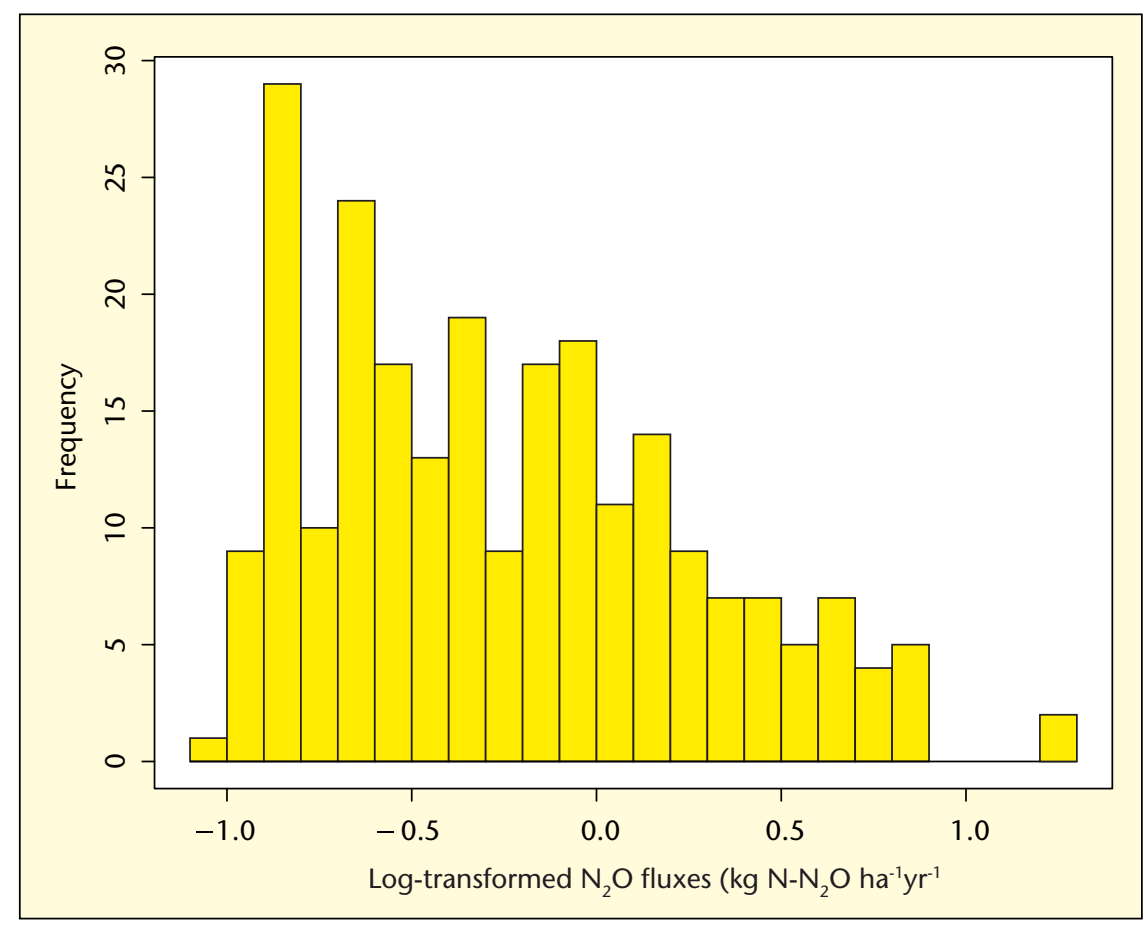

Figure 2. Histogram of log-transformed simulated fluxes across the various soil type units in the three sub-regions.

\section{Sensitivity to fertilizer $N$}

At the sub-regional level, the model-based estimates of direct $\mathrm{N}_{2} \mathrm{O}$ emissions from wheatcropped fields were $40 \%$ to $80 \%$ lower than the IPCC ones. The deviation was strongest in Beauce Dunoise and smallest in Faux-Perche, reflecting the ranking of the sub-regions respective to $\mathrm{NO}$ emissions on a per hectare basis. The background emissions simulated by CERES-EGC were also lower than the IPCC default value of $1 \mathrm{~kg} \mathrm{~N}_{2} \mathrm{O}-\mathrm{N} \mathrm{ha}^{-1}$, but to a lesser extent than the total emissions, and ranged from 0.52 to $1.02 \mathrm{~kg} \mathrm{~N}_{2} \mathrm{O}-\mathrm{N} \mathrm{ha}^{-1}$. As a result, model-based $\mathrm{EF}_{d}$ estimates were extremely low compared to the IPCC default $(0.0125 \pm 0.01 \mathrm{~kg}$ $\mathrm{N}_{2} \mathrm{O}-\mathrm{N} \mathrm{kg}{ }^{-1} \mathrm{~N}$ ), ranging from 0.0007 to $0.0033 \mathrm{~kg} \mathrm{~N}_{2} \mathrm{O}-\mathrm{N} \mathrm{kg} \mathrm{k}^{-1} \mathrm{~N}$. This low sensitivity of model results to fertilizer $\mathrm{N}$ essentially arose from the fact that a major fraction of the emissions happened outside the spring season during which fertilizer was applied. Some emissions occurred prior to wheat planting in the fall of 1998, or in the late summer and fall of 1999 [11]. Because wheat crops actively took up soil $\mathrm{N}$ during their growing season, fertilization actually had little influence on the soil inorganic content upon harvest in summer, and on the subsequent emissions of $\mathrm{N}_{2} \mathrm{O}$.

Secondly, $\mathrm{N}_{2} \mathrm{O}$ emissions were generally proportional to the amount of fertilizer $\mathrm{N}$ applied to crops, whatever the range of fertilizer doses (figure 3). As a result, the average EFs estimated by fitting a straight line to the response curve obtained by using emissions data only for the nominal and zero doses of fertilizer $\mathrm{N}$, as is usually done in the IPCC method. The straight line corresponds to the IPCC relationship.

\section{Discussion}

\section{Empirical and model-based emission factors}

There is a growing body of literature on the determination of direct emission factors $\left(\mathrm{EF}_{d} s\right)$ from field measurements at the plot-scale. These factors have been shown to be extremely variable from one field to the other, ranging from 0.0003 to $0.068 \mathrm{~kg} \mathrm{~N}_{2} \mathrm{O}-\mathrm{N} \mathrm{k}^{-1} \mathrm{~N}$ [23-26]. There are many sources of uncertainty behind these empirical estimates: quantification of background emissions, spatial and temporal coverage, and time-frame on which the measurements are carried out, which all warrant corrections [26]. According to the latter reference, the absence of background emissions data is expected to lead to an over-estimation of $\mathrm{EF}_{d} s$, by $15 \%$ to $110 \%$ under Chinese conditions. Conversely, a shortage of temporal coverage (insufficient frequency of measurements) would lead to an under-estimation by $19 \%$ to $30 \%$.

Process-based models should not require any such corrections since they simulate $\mathrm{N}_{2} \mathrm{O}$ emissions continuously over time, and can predict fertilized as well as unfertilized crops. Thus, they may be expected to supply $\mathrm{EF}_{d}$ values up to $80 \%$ lower than the empirical estimates listed above, among which the IPCC methodology. Such was the case with the $\mathrm{EF}_{d} s$ simulated with CERES-EGC, which fell in the lower

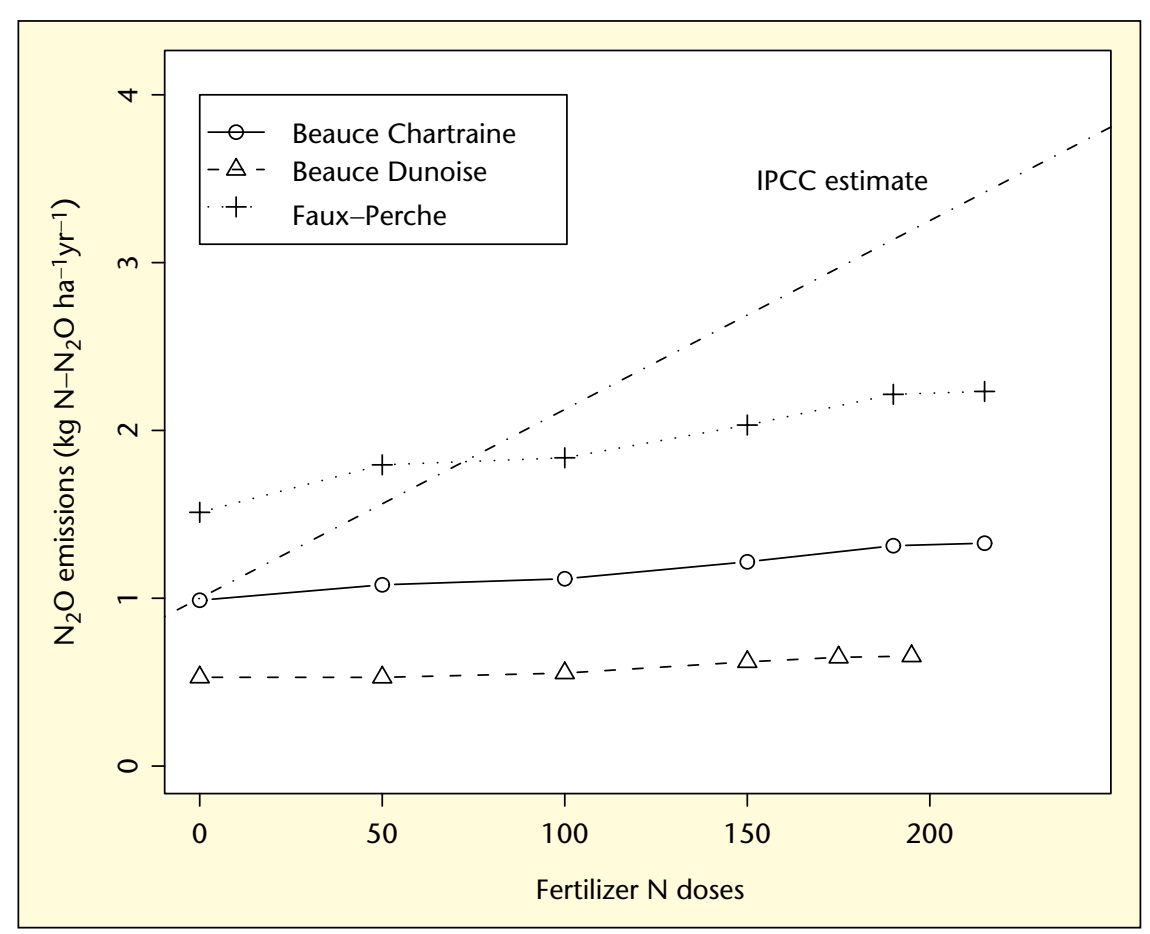

Figure 3. Simulated relationships between fertilizer $N$ dose and year-round NO emissions at the sub-regional level. 
range of the IPCC values. Similarly, another modeling study reported an average $\mathrm{EF}_{d}$ of $0.008 \mathrm{~kg} \mathrm{~N}_{2} \mathrm{O}-\mathrm{N} \mathrm{kg}^{-1} \mathrm{~N}$ with a $0.0025-0.04 \mathrm{~kg}$ $\mathrm{N}_{2} \mathrm{O}-\mathrm{N}^{-1} \mathrm{~kg} \mathrm{~N}$ range for cropland in China [26]. Calculation of $\mathrm{EF}_{d} s$ without the control term (i.e. assuming zero emissions for unfertilized crops), as was done in a number of studies for lack of background emissions data [30], resulted in EFs ranging between 0.0033 and $0.0104 \mathrm{~kg} \mathrm{~N}_{2} \mathrm{O}-\mathrm{N} \mathrm{kg}^{-1} \mathrm{~N}$. This falls within the lower half of the IPCC range ( 0.0025 to 0.0225 $\mathrm{kg} \mathrm{N}_{2} \mathrm{O}-\mathrm{N} \mathrm{kg}^{-1} \mathrm{~N}$ ).

Fertilizer type is also mentioned to affect the values of $\mathrm{EF}$, although there is a lack of sufficient data to derive generic, fertilizer-specific figures $[27,28]$. Bouwman [28] reported $\mathrm{EF}_{d}$ values of $0.003 \pm 0.003 \mathrm{~kg} \mathrm{~N}_{2} \mathrm{O}-\mathrm{N} \mathrm{kg}^{-1} \mathrm{~N}$ for ammonium nitrate and urea, the two types of fertilizers used in the sub-regions simulated here. Lastly, $\mathrm{EF}_{d} s$ should capture some range of interannual variability. It is in principle possible with a model like CERES-EGC, but we considered it beyond scope here since we focused on spatial extension from plot-scale to regional scale. However, our results are to a large extent conditioned by the growing season in which the experiments and simulations were run. Investigating the effect of inter-annual climate variability is therefore a major prospect for future work on $\mathrm{N}_{2} \mathrm{O}$ simulations.

\section{Factors controlling $\mathrm{N}_{2} \mathrm{O}$ emissions at the regional scale}

Two major differences occurred between the model-based and IPCC estimates of $\mathrm{N}_{2} \mathrm{O}$ emissions at the sub-regional scale: the magnitude of the emissions, and the response to fertiliser $\mathrm{N}$. Both appeared much weaker with the model, and are discussed below. The lack of response to fertilization essentially occurred because the simulated $\mathrm{N}_{2} \mathrm{O}$ emissions were not concentrated in the spring season when fertilizer was applied. However, it may also be a result of the upscaling from field- to regionalscale. The literature on spatial extension of $\mathrm{N}_{2} \mathrm{O}$ fluxes, whether using process-based models or more empirical methods, shows the 'fertilizer dose' factor to lose some influence in favor of environmental characteristics, as the spatial area increases. At the European scale, Freibauer [29] modeled $\mathrm{N}_{2} \mathrm{O}$ emissions based on pedological and agronomic factors, and found a coefficient of only $0.4 \%$ in the correlation between these emissions and fertilizer doses. In a review of emission data covering a wide range of crop management and geographical locations, Kaiser et al. [25] report a similar coefficient with a value of $0.6 \%$. These figures could be interpreted as an average $\mathrm{EF}_{d}$ of 0.004 to $0.006 \mathrm{~kg} \mathrm{~N}_{2} \mathrm{O}-\mathrm{N} \mathrm{kg}^{-1} \mathrm{~N}$ for Europe. The apparent discrepancy between the ranges of $\mathrm{EF}_{d} s$ obtained at the plot and regional scales may be due to an uneven sampling of field sites biased towards the more $\mathrm{N}_{2} \mathrm{O}$-productive sites, when establishing empirical $\mathrm{EF}_{d} \mathrm{~s}$, and these sites might turn out to represent only a small proportion of total arable land. Such was the case in our study since the test sites were actually above average in terms of $\mathrm{N}_{2} \mathrm{O}$ emissions. The frequent lack of background data in these experiments is also a source of bias since a significant part of the emissions attributed to fertilizer use might actually be related to the soil potential per se, as happened in our simulations. For urea and ammonium-nitrate type fertilizers, Bouwman [27] reported relative differences as high as $100 \%$ between $\mathrm{EF}_{d}$ estimates including or not an unfertilized control. Regarding the magnitude of the simulated fluxes, the study by Li et al. [6] at the country level revealed a clustered spatial pattern for $\mathrm{N}_{2} \mathrm{O}$ emissions, with contrasting efflux rates between groups of counties (equivalent to our sub-regions). It is thus probable that some subregions would contribute significantly less $\mathrm{N}_{2} \mathrm{O}$ than others, which seems to be the case with those we had selected here. On the other hand, the IPCC $\mathrm{EF}_{d}$ are representative at a global or continental scale, as they were obtained from observations worldwide, rather than at the subregional level. Overall, in our sub-regions, $\mathrm{N}_{2} \mathrm{O}$ emission levels primarily depend on a local potential set by climatic conditions combined with soil microbiological and physical properties, with the influence of crop management appearing somewhat minor in the expression of this potential. As a consequence, reducing fertilizer $\mathrm{N}$ would seemingly have little effect on abating $\mathrm{N}_{2} \mathrm{O}$ fluxes. However, the fertilizer dose also influences the residual $\mathrm{N}$ content upon sowing of the proceeding crop, which significantly affected the sub-regional $\mathrm{N}_{2} \mathrm{O}$ efflux.

Based on the above discussion of the factors influencing $\mathrm{N}_{2} \mathrm{O}$ emissions, it appears that results with oilseed rape crops would be similar to those obtained here on wheat crops. The $\mathrm{N}_{2} \mathrm{O}$ efflux is likely to be slightly lower with oilseed rape because of the capacity of the latter to take up residual soil inorganic $\mathrm{N}$ in the autumn after sowing, but the mineralization of $\mathrm{N}$-rich rapeseed residues may enhance $\mathrm{N}_{2} \mathrm{O}$ emissions after harvest [25].

As a conclusion, under such mild temperate climatic conditions as investigated here, mitigation measures should target a reduction in the amount of soil mineral $\mathrm{N}$ in autumn, and a decrease of the soil $\mathrm{N}_{2} \mathrm{O}$ production potential itself. While there is a range of best management practices available to address the first point, there is a need for future research on the microbial and physical determinants of soil emission potentials, and how they may be affected by crop management.
Acknowledgments. Financial support from the French Ministry for the Environment (through its GESSOL grant program) is acknowledged.

\section{REFERENCES}

1. MOSIER AR, KROEZE C, NEVISON C, OENEMA O, SEITZINGER S, VAN CLEEMPUT O. Closing the global $\mathrm{N}_{2} \mathrm{O}$ budget: nitrous oxide emissions through the agricultural nitrogen cycle. Nutr Cycl Agroecosyst 1998; 52: 225-48.

2. DUXBURY JM, BOULDIN DR. Emission of nitrous oxide from soils. Nature 1982; 298: 462-4.

3. IPCC. Guidelines for national greenhouse gas inventories: greenhouse gas inventory reference manual, revised 1996. Bracknell, UK: IPCC/OECD/IGES, 1997.

4. LI CS, FROLKING S, XIAO XM, et al. Modeling impacts of farming management alternatives on $\mathrm{CO} 2, \mathrm{CH} 4$, and $\mathrm{N} 2 \mathrm{O}$ emissions: A case study for water management of rice agriculture of China. Global Biogeochem Cycles 2005; 19: GB3010.

5. MUMMEY DL, SMITH JL, BLUHM G. Assessment of alternative soil management practices on $\mathrm{N}_{2} \mathrm{O}$ emissions from US agriculture. Agric Ecosyst Environ 1998; 70: 79-97.

6. LIC, ZHUANG Y, CAOM. Comparing a process-based agro-ecosystem model to the IPCC methodology for developing a national inventory of $\mathrm{N} 2 \mathrm{O}$ emissions from arable lands in China. Nutr Cycl Agroecosys 2001; 60: 15975.

7. BUTTERBACH-BAHL K, KESIK M, MIEHLE $P$, PAPEN H, LI C. Quantifying the regional source strength of $\mathrm{N}$-trace gases across agricultural and forest ecosystems with process based models. Plant Soil 2004; 260: 311-29.

8. GRANT RF. PATTEY E. Modelling variability in $\mathrm{N}_{2} \mathrm{O}$ emissions from fertilized agricultural fields. Soil Biol Biochem 2003; 35: 225-43.

9. JONES CA, KINIRY JR. Ceres-N Maize: a simulation model of maize growth and development. College Station, Temple, TX: Texas A\&M University Press, 1986.

10. GABRIELLE $B$, LAVILLE $P$, HENAULT C NICOULLAUD B, GERMON JC. Simulation of nitrous oxide emissions from wheat-cropped soils using CERES. Nutr Cycl Agroecosyst 2006; 74: 133-46.

11. GABRIELLE $B$, LAVILLE $P$, DUVAL $O$, NICOULLAUD B, GERMON JC, HÉNAULT C. Process-based modeling of nitrous oxide emissions from wheatcropped soils at the sub-regional scale. Global Biogeochem Cycles 2006; 20: GB4018.

12. HENAULT C, BIZOUARD F, LAVILLE $P$, et al. Predicting in situ soil $\mathrm{N} 2 \mathrm{O}$ emissions using NOE algorithm and soil data base. Glob Change Biol 2005; 11: 115-27. 
13. HENAULT C, GERMON JC. Nemis, a predictive model of denitrification on the field scale. Agronomie 2000; 51: 257-70.

14. HENAULT C, CHENEBY D, HEURLIER K, GARRIDO F, PEREZ S, GERMON JC. Laboratory kinetics of soil denitrification are useful to discriminate soils with potentially high levels of $\mathrm{N}_{2} \mathrm{O}$ emission on the field scale. Agronomie 2001; 21: 713-23.

15. GARRIDO F, HENAULT $C$, GAILLARD $H$, PEREZ S, GERMON JC. $\mathrm{N}_{2} \mathrm{O}$ and $\mathrm{NO}$ emissions by agricultural soils with low hydraulic potentials. Soil Biol Biochem 2002; 34: 559-75.

16. PARTON W], HOLLAND EA, DEL GROSSO SI, et al. General model for NOx and $\mathrm{N}_{2} \mathrm{O}$ emissions from soils. / Geophys Res 2001; 106: 17403-19.

17. ISAMBERT M. Carte pédologique 1/100 000 de Châteaudun. Notice explicative. Technical report. Paris: INRA Edition, 1984.

18. KING D, DAROUSSIN J, JAMAGNE M. Proposal for a spatial organization model in soil science (the example of the European Communities soil map). . Am Soc Inform Sci 1994; 45: 705-17.
19. BASTET G, BRUAND A, QUETIN P, COUSIN I. Estimation des propriétés de rétention en eau des sols à l'aide de fonctions de pédo-transfert (FPT). Etude Gestion Sols 1998; 5: 7-28.

20. ARROUAYS D, DESLAIS W, DAROUSSIN ], et al. Stocks de carbone dans les sols de France. Quelles estimations? CR Acad Agric Fr 1999; 85: 278-92.

21. ULRICHE, WILLOT $B$. Les dépôts atmosphériques en France de 1850 à 1990. Synthèse. Paris: ADEME/ONF/INRA, Office National des Forêts, 1993.

22. ISSS/ISRIC/FAO. World Reference Base for soil resources. World Soil Resources Rep 1998; 84; (FAO, Rome).

23. FLESSA H, RUSER R, DORSCH P, KAMP T, JIMENEZ MA, MUNCH JA. Integrated evaluation of greenhouse gas emissions $(\mathrm{CO}, \mathrm{CH}, \mathrm{N2O})$ from two farming systems in southern Germany. Agric Ecosys Environ 2002; 91: 175-89.

24. VELTHOF GL, KUIKMAN PJ, OENEMA O. Nitrous oxide emission from animal manures applied to soil under controlled conditions. J Environ Qual 2003; 37: 221-30.
25. KAISER EA, KOHRS K, KUCKE M, SCHNUG E, HEINEMEYER O, MUNCHC. Nitrous oxide release from arable soil: importance of $\mathrm{N}$ fertilization, crops and temporal variation. Soil Biol Biochem 1998; 30: 1553-63.

26. ZHENG $X$, HAN S, HUANG $Y$, WANG $Y$, WANG M. Re-quantifying the emission factors based on field measurements and estimating the direct $\mathrm{N}_{2} \mathrm{O}$ emission from Chinese croplands. Global Biogeochem Cycl 2004; 18; (GB2018).

27. BOUWMAN AF. Direct emissions of nitrous oxide from agricultural soils. Nutr Cycl Agroecosyst 1996; 46: 53-70.

28. MOSIER AR, DUXBURY JM, FRENEY JR, HEINEMEYER O, MINAMI K. Nitrous oxide emissions from agricultural fields: Assessment, measurement and mitigation. Plant Soil 1998; 181: 95-108.

29. FREIBAUER A. Regionalised inventory of biogenic greenhouse gas emissions from European agriculture. Eur J Agron 2003; 19: 135-60. 